\title{
Pengalaman ibu hamil berisiko tinggi dalam memutuskan tempat persalinan rujukan di Puskesmas Mlati II
}

\section{The experience of high-risk pregnant women in deciding the selection of referral labor place at Puskesmas Mlati II}

\author{
Budi Susilawati $^{1}$, Djaswadi Dasuki ${ }^{2}$, Ahsanudin Attamimi ${ }^{3}$, Farida Kartini ${ }^{4}$ \\ ${ }^{1}$ Mahasiswa Prodi Ilmu Kebidanan Program Magister, Universitas ‘Aisyiyah, Yogyakarta, Indonesia \\ ${ }^{2,3}$ Dosen Universitas Gadjah Mada, Yogyakarta, Indonesia \\ ${ }^{4}$ Dosen Universitas ‘Aisyiyah, Yogyakarta, Indonesia
}

bsusilawati75@ugm.ac.id ${ }^{1}$; djaswadi@ugm.ac.id ${ }^{2}$; ahsanudinspog@ugm.ac.id ${ }^{3}$; faridakartini@unisayogya.ac.id ${ }^{4}$

Tanggal Submisi: 6 Oktober 2020, Tanggal Penerimaan: 28 November 2020

\begin{abstract}
Abstrak
Kehamilan berisiko tinggi dianggap sebagai ancaman serius bagi kesehatan dan kehidupan ibu hamil dan bayi. Sekitar 20 juta wanita di seluruh dunia memiliki kehamilan berisiko tinggi dan lebih dari 800 meninggal setiap hari, salah satunya dipengaruhi oleh pilihan tempat persalinan dan rujukan pada saat mencari pertolongan. Ada banyak faktor yang mempengaruhi pengambilan keputusan tempat rujukan pada ibu hamil dengan resiko tinggi santra lain biaya, transportasi, pengaruh agama dan budaya termasuk wilayah tempat tinggal dan tingkat pendidikan perempuan (Yahya \& Pumpaibool, 2019). Tujuan penelitian ini untuk mengetahui Pengalaman Ibu Hamil Berisiko Tinggi Dalam Memutuskan Pemilihan Tempat Persalinan Rujukan Di Puskesmas Mlati II. Metode Penelitian Kualitatif Dengan Rancangan DeskriptifNaratif. Semi-structure interview digunakan untuk wawancara 10 ibu hamil berisiko tinggi dan dua informan pendukung. Dari hasil wawancara didapatkan bahwa banyk faktor yang memopengaruhi pemilihan fasilityas rujukan antara lain pengalaman pribadi, keluarga, teman, atau orang lain. Selain itu Pemilihan tempat persalinan dipengaruhi oleh jarak antara rumah dengan rumah sakit rujukan, dipengaruhi juga oleh ketersediaan fasilitas rumah sakit yang memadai, dan dipengaruhi oleh alur pelayanan dan kepemilikan jaminan asuransi. Dari kesemua faktor kepemilikan asuransi menjadi faktor yang paling banyak disebutkan hal ini teritama terkait alur rujukan pelayanan dan baiaya terkait Tindakan persalinan.
\end{abstract}

Kata Kunci: hamil berisiko tinggi; pengalaman ibu; tempat persalinan

\section{Abstract}

Background: High-risk pregnancy is considered a severe threat to the health and life of pregnant women and babies. About 20 million women worldwide have high-risk pregnancies, and more than 800 die each day. All women want a normal birth without intervention; they need emotional support from their partner or family, need antenatal education, and support from health professionals. High-risk pregnancies have physical complications during pregnancy so that the health of the mother and the fetus is threatened. As well as psychological conditions. To find out the experience of high-risk pregnant women in deciding the selection of 
a referral delivery place at Puskesmas (Primary Health Center) Mlati II. It was qualitative research with a descriptive-narrative design. Semi-structured interviews were used to interview ten high-risk pregnant women and two supporting informants. The mother's experience of selecting the labor place was influenced by personal experiences, family, friends, or other people. The selection of a labor place could be affected by the distance between the house and the referral hospital. It was also influenced by the availability of adequate hospital facilities, and by the service stream and ownership of insurance coverage. mothers learn more about high-risk pregnancies so that they are better prepared to face and prepare for needs, including selecting an advanced-level labor place.

Keywords: mother's experience, high-risk pregnancy, labor place

\section{PENDAHULUAN}

Kehamilan resiko tinggi adalah kehamilan yang memiliki risiko yang lebih besar dari biasanya bagi ibu maupun bayinya, yang akan menyebabkan terjadinya penyakit atau kematian sebelum maupun sesudah persalinan (Kemenkes, 2014). Seorang wanita hamil mempunyai potensi berisiko selama kehamilan, persalinan, dan nifas. Kondisi medis atau obstetrik berbahaya tak terduga dan potensial yang berhubungan dengan kehamilan terhadap kesehatan atau kesejahteraan ibu dan janin dianggap sebagai kehamilan yang berisiko tinggi (Holness, 2018). Sekitar 20 juta wanita di seluruh dunia memiliki kehamilan berisiko tinggi dan lebih dari 800 meninggal setiap hari. Persentase kehamilan berisiko tinggi meningkat dari 6\% menjadi 33\% karena kondisi kehamilan berisiko tinggi yang bervariasi. Di seluruh dunia, 5\% $-10 \%$ dari seluruh ibu hamil mengalami penyulit selama kehamilan antara lain preeklamsia dan resiko kehamilan lainnya seperti malaria, TBC, dan anemia defisiensi besi kronis (Holness, 2018).

Setiap wanita mempunyai harapan untuk dapat melahirkan normal, mendapat dukungan emosional dari pasangan dan keluarga, mendapatkan pendidikan antenatal, mendapat dukungan dari tenaga kesehatan, menjalani proses melahirkan yang positif, mendapatkan perawatan intrapartu yang berkualitas, mendapatkan lingkungan perawatan yang kondusif, kesiapan menghadapi proses kelahiran dipengaruhi oleh kualitas perawatan oleh tenaga kesehatan (Deliktas Demirci et al., 2018). Ada beberapa perspektif tentang penolong persalinan yang diungkapkan oleh beberapa perempuan dimana umumnya perempuan merasa jika persalinan ditolong oleh dokter kandungan cenderung lebih beresiko dan tidak alami, namun sebaliknya jika melahirkan ditolong bidan maka persalinan cenderung lebih alami(Lee et al., 2016). Ada banyak faktor yang mempengaruhi keputusan perempuan dalam memanfaatkan fasilitas Kesehatan yang dipilih pada saat bersalin antara lain biaya, transportasi, pengaruh agama dan budaya termasuk wilayah tempat tinggal dan tingkat pendidikan perempuan (Yahya \& Pumpaibool, 2019). Penelitian ini bertujuan mengeskplorasi pengalaman ibu bersalin dengan resiko tinggi dalam mencari tempat rujukan.

\section{METODE}

Jenis penelitian ini adalah penelitian kualitatif dengan rancangan deskriptif-naratif. Subjek dalam penelitian adalah ibu hamil berisiko tinggi Ibu hamil dengan usia kehamilan trimester dua dan tiga yang melakukan pemeriksaan kehamilan di Puskesmas Mlati II Kabupaten Sleman sejumlah 10 informan ibu hamil sebagai informan inti, satu orang suami sebagai informan pendukung, dan satu bidan sebagai informan pendukung. Melakukan wawancara mendalam dengan menggunakan pedoman wawancara terkait Pengalaman Ibu 
Hamil Berisiko Tinggi Dalam Memutuskan Pemilihan Tempat Persalinan Rujukan. Pegambilan data dilakukan dengan wawancara mendalam. Proses wawancara mendalam dilakukan kurang lebih 20-30 menit (Creswell, 2016). Data yang diperoleh di reduksi untuk memberikan gambaran yang jelas. Penyajian data dalam penelitian ini di sajikan dalam bagan kemudian dalam bentuk tes naratif. Kemudian dilakukan verifikasi dan penarikan kesimpulan agar kesimpulan yang dikemukakan merupakan kesimpulan yang kredibel (Creswell, 2016).

\section{HASIL DAN PEMBAHASAN}

Diagram di bawah ini menggambarkan tema dan subtema tentang pengalaman ibu hamil berisiko tinggi dalam memutuskan tempat persalinan rujukan:

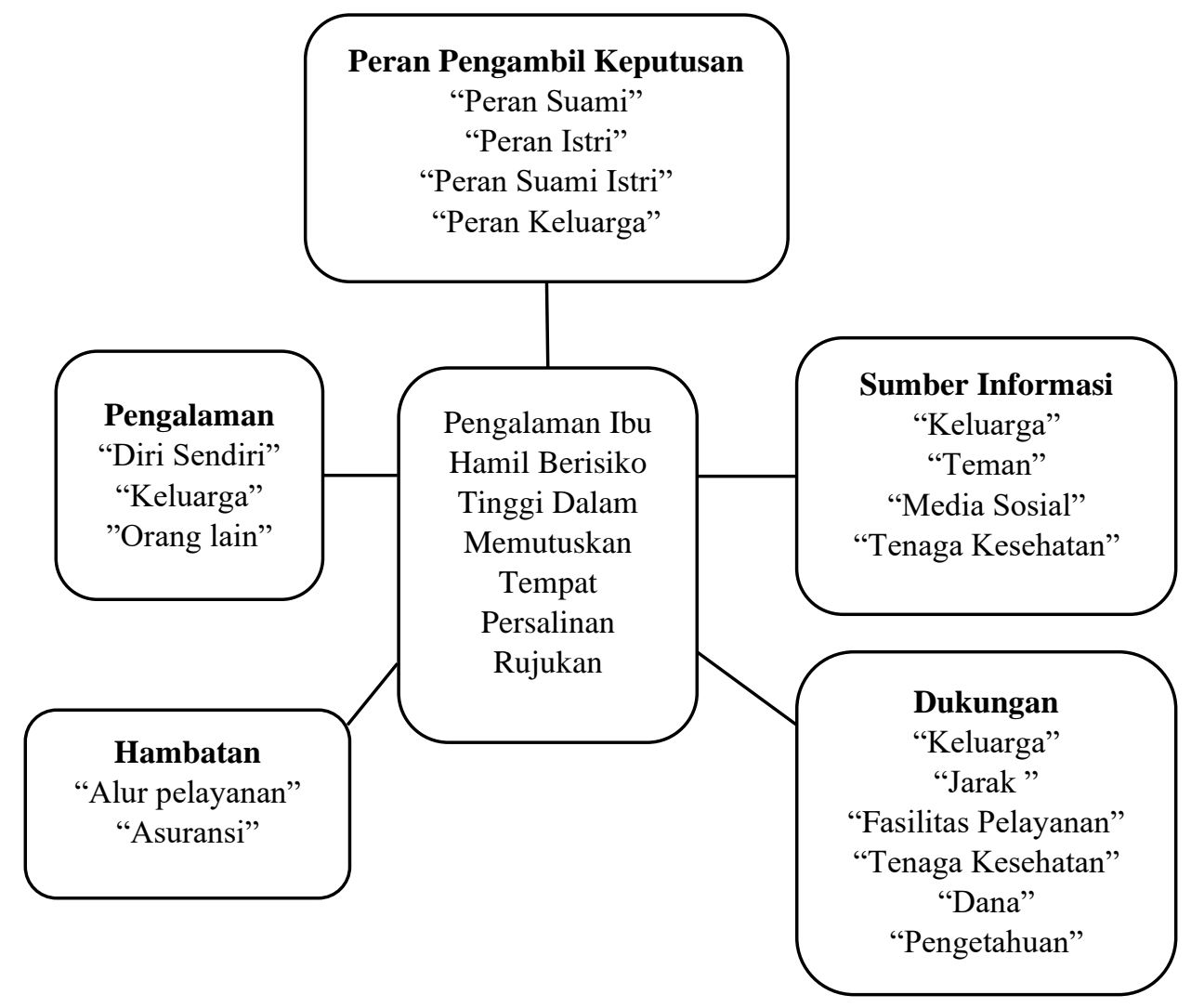

Tema peran pengambil keputusan terkait dengan pengambilan keputusan dilakukan oleh siapa dengan subtema yaitu: "Peran Suami Istri", "Peran Keluarga", dan "Peran Tenaga Kesehatan". 


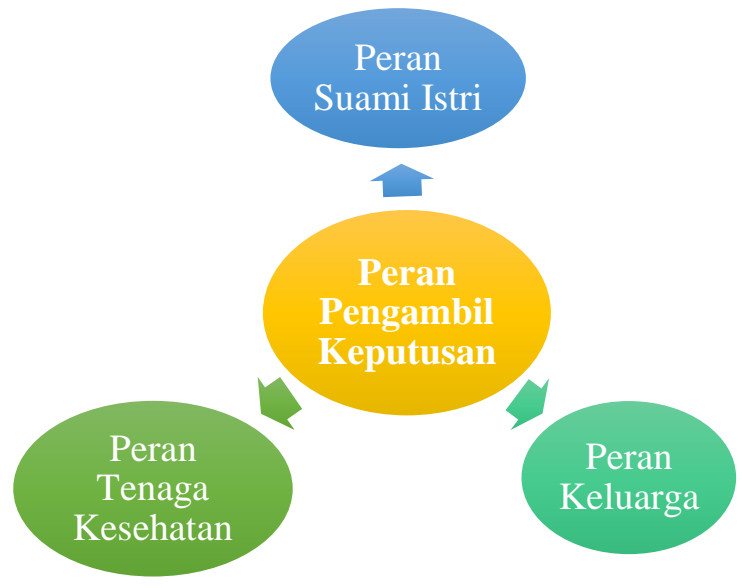

1. Subtema "peran suami istri" mendiskripsikan tentang peran suami dan istri dalam mengambil keputusan dan menentukan pilihan tempat persalinan, dimana sebelum memutuskan memilih tempat persalinan mereka berdiskusi dulu, seperti yang disampaikan informan 1, 3, dan 8 sebagai berikut: "Yang menentukan: saya sama suami, soalnya kan pasti diobrolin dulu, keputusan bersama"(Inf 1). "Saya sendiri tapi kan yaa atas persetujuan suami”'(Inf 3). "Suami...ya berdua sih bu... saya dan suami”(Inf 8).

2. Subtema "peran keluarga" mendiskripsikan peran keluarga dalam membantu mengambil keputusan dan menentukan pilihan tempat persalinan, seperti yang disampaikan oleh Informan 9, dan 10 sebagai berikut: "Sama keluarga juga ...kalo saya sih ngikut saja”"(Inf 9). "Sama bapak... kalo aku, bapak kemarin sama suami dan sama Mas”(Inf 10).

3. Subtema "peran tenaga kesehatan" menggambarkan tentang keputusan memilih tempat persalinan mengikuti arahan tenaga kesehatan, seperti yang disampaikan oleh Informan 3 sebagai berikut: "Belum tau kalo disini nanti dikasi rujukannya dimana, gimana yaaa....yaa masih pikir-pikir...hehee...ya demi kebaikan kelancaran itu too....ya ikuti saran bidan"(Inf 3).

Tema pengalaman ibu terkait memilih tempat persalinan berdasarkan dari pengalaman dari siapa dengan subtema yaitu: "Diri Sendiri", "Keluarga", "Orang Lain".

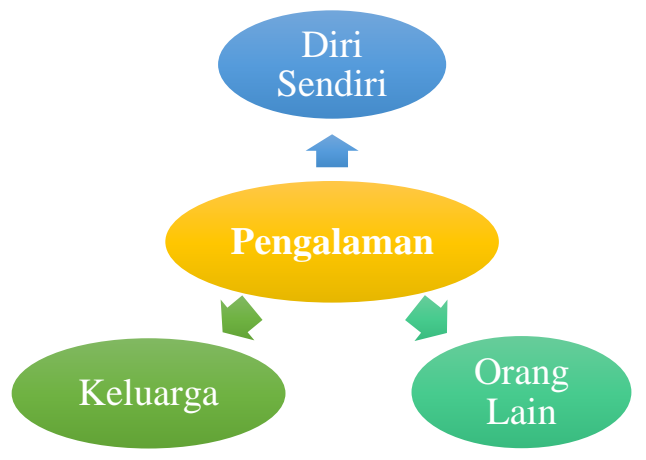

1. Subtema "diri sendiri" menggambarkan pemilihan tempat persalinan berdasarkan pengalaman diri sendiri, seperti yang disampaikan oleh Informan 9 sebagai berikut: "Kalo mau melahirkan dimana gitu, karena dulu sudah pernah di rs " $S$ " itu sdh tidak saya pikirkan lagi”(Inf 9). 
2. Subtema "keluarga" mendiskripsikan pemilihan tempat persalinan berdasarkan pengalaman dari keluarga, seperti yang disampaikan oleh informan 5 dan 7 sebagai berikut:

"Kebanyakan beberapa sodara kesana gitu”(Inf 5). "Udah...soale kakak dua-duanya disana lairannya"(Inf 7).

3. Subtema "orang lain" menggambarkan pemilihan tempat persalinan berdasarkan pengalaman dari orang lain, seperti yang disampaikan oleh informan 1 dan 8 sebagai berikut: "yaa soalnya banyak yang rekomendasiin disitu, soalnya tetangga juga disitu”(Inf 1). "Ya dari temen-temen"(Inf 8).

Tema dukungan disini berkaitan dengan memilih tempat persalinan berdasarkan dari dukungan yang di kategorikan menjadi subtema yaitu: "Jarak", "Keluarga", "Fasilitas Pelayanan”, "Dana”, "Pengetahuan”, dan ”Tenaga Kesehatan”.

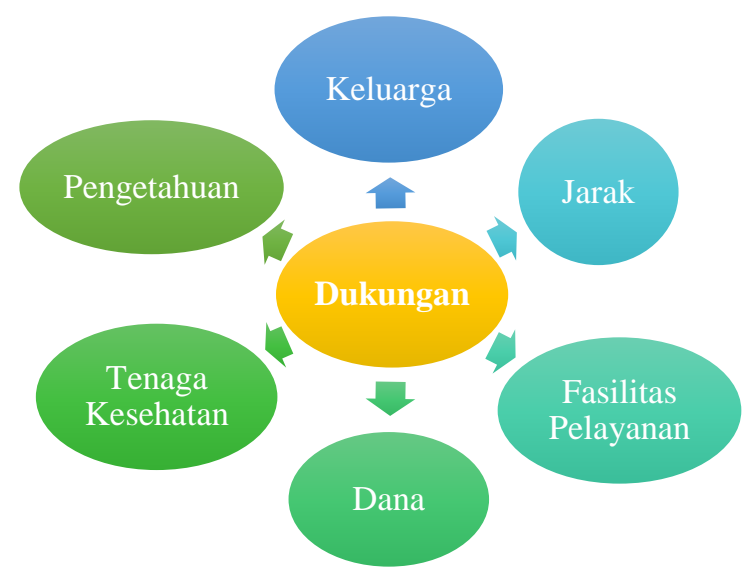

1. Subtema "keluarga" menggambarkan dukungan keluarga pada kehamilan ibu dan pemilihan tempat persalinan, seperti yang disampaikan oleh informan 5 sebagai berikut: "Kalo saya bilang ke suami..terus saya pengennya ini...ya saling ini sih bu pertimbangan ...apalagi suami juga mikire terserah kamu, yang penting kamu nyaman, terus ga terbebani ga stress gitu-gitu"(Inf 5).

2. Subtema "jarak" menggambarkan tentang jarak rumah dengan rumah sakit rujukan, dimana jarak juga akan menjadi pertimbangan informan saat memilih rumah sakit rujukan, seperti yang diutarakan oleh informan 4 sebagai berikut: "Ya Kalo bisa sih ya mungkin yang agak deket ga terlalu jauh sama tempat tinggal...ya antara kalo sekitar sini kan mungkin antara "QL" atau "SI" ...pokoknya yang ga terlalu jauh"(Inf 4).

3. Subtema "fasilitas pelayanan" menggambarkan tentang pemilihan rumah sakit rujukan, dimana fasiltas pelayanan rumah sakit juga menjadi pertimbangan informan saat memilih rumah sakit rujukan, seperti yang diutarakan oleh informan 7 sebagai berikut: "Soalnya disana pelayanannya bagus, fasilitasnya juga bagus "(Inf 7).

4. Subtema "dana" menggambarkan tentang persiapan dana selain asuransi, dimana beberapa informan mengetahui apabila sewaktu-waktu asuransi tidak bisa digunakan, seperti yang diutarakan oleh informan 5 sebagai berikut: "Punya..kan sebelum menikah sudah mempersiapkan, saya ada tabungan khusus buat persalinan lah"(Inf 5).

5. Subtema "pengetahuan" menggambarkan pengetahuan dari informan tentang risiko kehamilan yang dialami saat ini, seperti yang diutarakan oleh informan 5 sebagai berikut: "Kalo sebelumnya kan semenjak hamil kan sudah searching-searching...eee kalo,plasenta agak dibawah itu setau saya ada macam-macamnya, kaya plasenta previa 
itu kan yang dibawah menutupi jalan lahir...terus saya juga baru searching penyebabnya apa itu belum diketahui secara pasti gitu katanya yang pas searching"(Inf 5).

Tema "sumber informasi" menggambarkan darimana informan mendapatkan informasi rumah sakit rujukan dengan subtema yaitu: "Keluarga", "Teman", "Media Sosial”, dan "Tenaga Kesehatan"

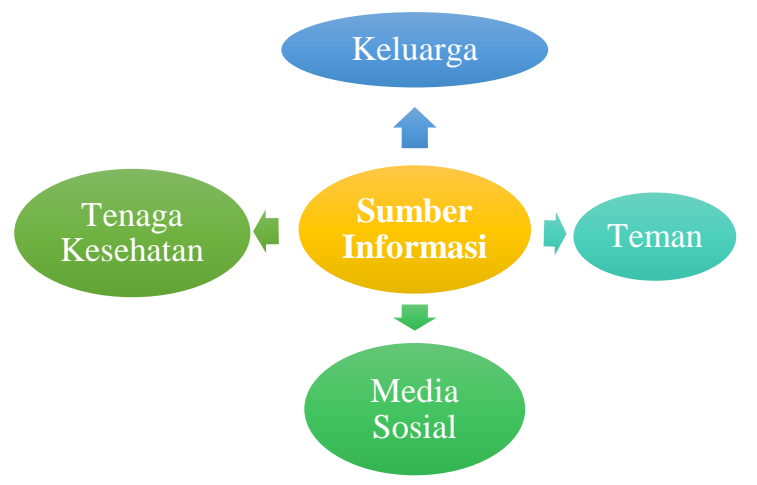

1. Subtema "keluarga" menggambarkan informasi yang diperoleh informan tentang rumah sakit yang menjadi pilihan saat akan melahirkan dari keluarga, seperti yang diutarakan oleh informan 10 sebagai berikut: "terus kakak-kakak kan bilang...iparnya bojoku (jawa: suami) kan berobat di rs " $U$ ”, dikasih tahu di rs " $U$ ”" saja " (Inf 10).

2. Subtema "teman" menggambarkan informasi yang diperoleh informan tentang rumah sakit yang menjadi pilihan saat akan melahirkan dari teman atau tetangga, seperti yang diutarakan oleh informan 8 sebagai berikut: "info nya ya dari temen-temen"(Inf 8).

3. Subtema "media sosial" menggambarkan informasi yang diperoleh informan tentang rumah sakit yang menjadi pilihan saat akan melahirkan dari media sosial, seperti yang diutarakan oleh informan 6 sebagai berikut: "Kalo puskesmas kan memang dari awal disaranin di puskesmas untuk cek rutin tiap bulannya, kalo untuk di klinik " $N$ " searching internet" (Inf 6).

4. Subtema "tenaga kesehatan" menggambarkan informasi dan anjuran tenaga kesehatan kepada informan tentang rumah sakit yang menjadi pilihan saat akan melahirkan dengan risiko tinggi, seperti yang diutarakan oleh informan 11 sebagai berikut: "Dianjurkan....ada dua pilihan...sama rumah sakit "QL" disuruh milih rumah sakit "U" atau rumah sakit "M"... saya milih rumah sakit "U" (Inf 11).

Tema "hambatan" menggambarkan bagaimana hambatan informan dalam memilih rumah sakit rujukan yang diinginkan dengan subtema yaitu: "Alur Pelayanan" dan "Asuransi" 


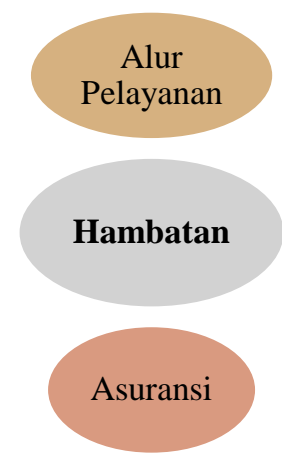

1. Subtema "alur pelayanan" mendiskripsikan bahwa pilihan rumah sakit untuk rujukan juga mengacu pada alur pelayanan, sehingga informan terkadang tidak bisa memilih sesuai keinginan mereka, seperti yang diungkapkan oleh Informan 9 sebagai berikut: "Sedikit tahu sih...jadi kalo yang kemarin itu malah pake yang punya suami, karena yang punya suami kan tingkatannya di satu, tempat saya itu dua ... alurnya paling ya surat rujukan dari dokter atau PPK 1, setelah itu baru dibawa ke rs yang dituju” (Inf 9).

2. Subtema "asuransi" mendiskripsikan bahwa pilihan rumah sakit untuk rujukan juga mengacu pada asuransi, sehingga informan terkadang tidak bisa memilih sesuai keinginan mereka karena asuransi punya aturan sendiri mengenai level rujukan, seperti yang diungkapkan oleh Informan 5 dan 12 sebagai berikut: "Pernah...soalnya saya kan juga udah nanya kalo bpjs itu kan dipake di rs itu juga ada aturannya...kalo misalnya kan harus...kalo misalnya mau pake bpjs kan harus ada rujukan dari faskes satu...kan faskes satu kan saya di puskesmas sini to, misalnya mau lairan di rs kan harus biasanya yang berisiko, misalnya kalo disini ndak bisa menangani baru dibawa kesana”(Inf 5).

\section{Pembahasan}

Beberapa informan dalam penelitian ini mengungkapkan keinginannya melakukan persalinan di rumah sakit yang sama karena pengalaman melakukan persalinan sebelumnya. Bagi seorang perempuan pengalaman melahirkan sebelumnya mempengaruhi perempuan dalam menentukan lokasi melahirkan dan menentukan pilihan bantuan. Serta pengalaman menggunakan fasilitas kesehatan sebelumnya (Treacy \& Sagbakken, 2015). Pengalaman merupakan faktor yang paling personal dalam menentukan kemana pasien ingin bersalin, pengalaman dan pelayanan yang baik dan memuaskan pada persalinan sebelumnya tentu saja menjadi hal yang paling mendasar ibu bersalin untuk Kembali memilih fasilitas Kesehatan pada persalinan kedua dan seterusnya. Selain itu kedekatan personal karena sudah pernah dan sudah kenal dengan dokternya atau bidannya menjadi faktor lain yang juga menguatkan pilihan pada tempat rujukan yang dicari pada saat bersalin.

Selain pengalaman pribadi secara umum informan dalam penelitian ini mendapatkan informasi mengenai rumah sakit tujuan yang dipilih berdasarkan berbagai sumber informasi antara lain dari keluarga, teman, media sosial, dan tenaga kesehatan, terutama untuk ibu yang baru pertama kali hamil dan melahirkan. Ibu ibu yang baru pertama kali melahirkan akan banyak bertanya kepada orang orang terdekat yang punya pengalaman sebelumnya terkait rekomendasi tempat persalinan yang dituju. selain informasi dari orang terdekat biasanya social media merupakan juga sumber pencarian informasi ibu ibu yang pertamakali melahirkan mulai dari jadwal periksa tarif dokter bahkan paket persalinan. Penelitian ini selaras dalam penelitian yang menyatakan bahwa informasi tentang pilihan dimana akan melahirkan dan sumber mana yang akan mereka percaya(Lee et al., 2014). Bidan memiliki kesempatan untuk 
meningkatkan kesadaran dan menyediakan informasi dan diskusi untuk wanita membuka pilihan tempat kelahiran (Henshall et al., 2018).

Faktor lain diluar pengalaman dan sumber informasi adalah faktor demografis yaitu jarak ke fasilitas Kesehatan. Dimana pada umumnya ibu ibu lebih memilih untuk mengakses layanan Kesehatan dengan jarak yang dekat ke tempat tinggalnya dibanding yang jauh dengan berbagai alasan, salah satu alasan yang dikemukakan oleh informan adalah jarak yang dekat memudahkana akses untuk keluarga yang menunggu dan ingin menjenguk pada saat persalinan. Hal ini sesuai yang disampaikan oleh Murray-Davis et al., 2012 bahwa secara umum pemilihan tempat persalinan dilakukan. berdasarkan jarak, dana, pengetahuan, fasilitas persalinan, dan dukungan dari tenaga kesehatan. (Murray-Davis et al., 2012). Hal ini juga sesuai dengan penelitian sebelumnya Pada penelitian disini beberapa informan mengungkapkan bahwa jarak antara rumah dan rumah sakit rujukan juga menjadi pertimbangan dalam memilih rumah sakit (Sukinem \& Hakimi, 2008).

Selain jarak fasilitas Kesehatan yang disediakan juga merupakan faktor penting yang menjadi pertimbanagan untuk ibu ibu bersalin memilih tempat persalinan termasuk juga jaminan Kesehatan yang dimiliki hal ini bisa dilihat dari hasil wawancara dimana secara umum beberapa informan mengungkapkan bahwa fasilitas pelayanan menjadi pertimbangan dalam memilih tempat persalinan, bahwa suatu pusat pelayanan yang menyediakan berbagai fasilitas dan layanan serta memiliki variasi produk akan menarik masyarakat untuk menggunakan jasanya. Fasilitas pelayanan medik yang memadai maka pelayanan yang diberikan kepada pasien diharapkan semakin baik (Connie et al., 2002). Rumah sakit dengan fasiltitas medis yang memadai juga menjadi pilihan ibu yang merencanakan bersalin di rumah sakit, selain karena persalinan berisiko tinggi juga beranggapan bahwa ini adalah penting untuk keselamatan ibu dan bayi (Coxon et al., 2014).

Namun demikian walaupun ada beberapa faktor yang mempengaruhi keputusan ibu dalam memilih tempat persalinan baik dari luar ataupun dari dalam akan tetapi keputusan mengenai akses dan penggunaaan layanan kesehatan bisa dipengaruhi oleh pendapat suami, orang tua, ibu mertua, dan anggota keluarga yang lain. seperti diungkapkan dalam jurnal menurut (Ganle et al., 2015). Secara umum dalam penelitian ini tidak ada perbedaan keinginan antara informan dengan suami ataupun keluarga, akan tetapi pilihan rumah sakit rujukan akan dibicarakan lagi dengan tenaga kesehatan apabila pilihan rumah sakit rujukan tidak sesuai dengan sistem asuransi dan alur rujukan. Hasil penelitian ini sejalan dengan ungkapan yang menyatakan bahwa faktor asuransi kesehatan memungkinkan seorang wanita bersalin ke fasilitas kesehatan, sehingga ibu dan bayi selamat(Moyer et al., 2013).

\section{SIMPULAN}

Pengalaman ibu memilih tempat persalinan dipengaruhi oleh pengalaman pribadi, keluarga, teman atau oleh orang lain. Pemilihan tempat persalinan bisa dipengaruhi oleh jarak antara rumah dengan rumah sakit rujukan, dipengaruhi juga oleh ketersediaan fasilitas rumah sakit yang memadai, jaminan Kesehatan dan dipengaruhi oleh alur pelayanan dan kepemilikan jaminan asuransi. 


\section{SARAN}

Ibu belajar lebih banyak tentang kehamilan risiko tinggi sehingga lebih siap menghadapi dan mempersiapkan keperluan termasuk memilih tempat persalinan tingkat lanjutan.

\section{REFERENCES}

Connie, S., Yakobus, S., \& Lenny. (2002). The Influence of Travel Time and Size of Shopping Center Towards The Requencies of Visiting Customers In Shopping Centers In Surabaya. Press Conference.

Coxon, K., Sandall, J., \& Fulop, N. (2014). To what extent are women free to choose where to give birth? How discourses of risk, blame and responsibility influence birth place decisions. 16, 51-67.

Creswell, J. (2016). Penelitian Kualitatif dan Desain Riset. Pustaka Pelajar.

Deliktas Demirci, A., Kabukcuglu, K., Haugan, G., \& Aune, I. (2018). I want a birth without interventions": Women's childbirth experiences from Turkey. Women Birth. https://doi.org/10.1016/j.wombi.2018.12.011

Depkes RI. (2011). Target Tujuan Pembangunan MDGs.

Ganle, J., Obeng, B., Segbefia, A., Mwinyur, V., Yeboah, J., \& Baatiema, L. (2015). How intra-familial decision-making affects women's access to, and use of maternal healthcare services in Ghana: a qualitative study. BMC Pregnancy and Childbirth, 15, 173.

Henshall, C., Taylor, B., Goodwin, L., Farre, A., Jones, M., \& Kenyon, S. (2018). Improving the quality and content of midwives' discussions with low-risk women about their options for place of birth: Co-production and evaluation of an intervention package. Midwifery, $59,118-126$.

Holness, N. (2018). High-Risk Pregnancy. The Nursing Clinics Of North America, 53(2), 241251.

Kemenkes. (2014). Profil Kesehatan Indonesia 2014. Kemenkes.

Lee, S., Ayers, S., \& Holden, D. (2014). A metasynthesis of risk perception in women with high risk pregnancies. Midwifery, 30(4), 403-411.

Lee, S., Ayers, S., \& Holden, D. (2016). Risk perception and choice of place of birth in women with high risk pregnancies: A qualitative study. Midwifery, 38.

Moyer, C., McLaren, Z., Adanu, R., \& Lantz, P. (2013). Understanding the relationship between access to care and facility-based delivery through analysis of the 2008 Ghana Demographic Health Survey. International Journal of Gynecology and Obstetrics, 122, 224-229.

Murray-Davis, B., Mcniven, P., Mcdonald, H., Malott, A., Elerar, L., \& Hutton. (2012). Why Home Birth? A Qualitative Study Exploring Women's Desision Making about Place of 
Birth in two Canadian Provinces. Journal Midwifery, 28, 576-581.

Sukinem, V., \& Hakimi, M. (2008). Pengaruh konseling oleh bidan terhadap keputusan ibu hamil memilih penolong dan tempat persalinan di Kabupaten Belu. universitas Gadjah Mada.

Treacy, L., \& Sagbakken, M. (2015). Exploration of perceptions and decision-making processes related to childbirth in rural Sierra Leone. BMC Pregnancy and Childbirth, $15(1), 87$.

Yahya, M., \& Pumpaibool, T. (2019). Factors influencing the decision to choose a birth center by pregnant women in Gombe state Nigeria. Journal of Health Research, 33(3), 228-237. 